\title{
Implementasi Total Quality Management (TQM) dalam sistem manajemen perencanaan kepala sekolah
}

\author{
Hiyasintus Ile Wulogening *, Agus Timan \\ Fakultas Ilmu Pendidikan, Universitas Negeri Malang. \\ Jl. Cakrawala No. 5, Sumbersari, Lowokwaru, Malang, Jawa Timur 65145, Indonesia. \\ * Corresponding Author. E-mail: sintuscyber@gmail.com
}

\section{ARTICLE INFO \\ Article History \\ Received: \\ 20 April 2020; \\ Revised: \\ 12 August 2020; \\ Accepted: \\ 15 August 2020 \\ Available online: \\ 25 September 2020}

\section{Keywords}

Kepala sekolah; Sistem manajemen; Principal;

Planning management system;

Total Quality

Management (TQM)

\begin{abstract}
Tujuan penelitian ini adalah menganalisis implementasi Total Quality Management (TQM) dalam sistem manajemen perencanaan kepala sekolah pada SMA Swasta Katolik. Penelitian ini menggunakan rancangan pendekatan kualitatif. Teknik pengumpulan data menggunakan teknik observasi, wawancara, dan studi dokumenter. Teknik analisis data yang digunakan meliputi reduksi data, penyajan data, menarik kesimpulan atau verifikasi data dan pengecekan keabsahan data menggunakan teknik triangulasi data. Temuan menunjukkan bahwa: 1.) Perencanaan program sekolah yang meliputi perumusan visi, misi, dan tujuan sekolah serta rencana kerja sekolah yang terdiri atas 12 program sudah dilaksanakan; 2 .) Rencana kerja bidang pendidikan telah disusun sesuai tupoksi dan kewajiban tenaga pendidik dan tenaga kependidikan seperti tertera dalam dokumen pedoman sekolah dan struktur organisasi sekolah yang telah diprogramkan; 3.) Kepala sekolah telah melakukan pengawasan dan evaluasi terhadap seluruh proses kegiatan sesuai program kerja sekolah dan telah menyusun dokumen rencana pengembangan sekolah; dan 4.) Kepala sekolah bersama staf dan dewan guru telah membangun sistem informasi manajemen guna mendukung pengimplementasian budaya mutu dalam seluruh aspek baik fisik maupun nonfisik.
\end{abstract}

This research aims to analyze the Total Quality Management (TQM) Implementation in The Principal Planning Management System at Catholic Privat High School. This research uses a qualitative approach design. Data collection techniques using observation techniques, interviews, and documentary studies. Data analysis techniques include data reduction, data intercepting, concluding/verifications, and data validity checking using data triangulation techniques. The findings show that: 1.) School program planning includes the formulation of the school and school work plan's vision, mission, and goals consisting of 12 programs that have been implemented; 2.) The work plan for the education sector has been prepared in accordance with the duties and responsibilities of teaching staff and education staff, as stated in the school guidelines document and school organization structure that has been programmed; 3.) The school principal has supervised and evaluated all the activities of activities according to the school work program and has compiled a school development plan document; and 4.) The principal with the school staff and the teachers have developed an information management system to support the implementation of culture quality in all aspects, both physical and non-physical.

This is an open access article under the CC-BY-SA license.

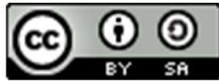

How to cite:

Wulogening, H. I., Supriyanto, A., \& Timan, A. (2020). Implementasi Total Quality Management (TQM) dalam sistem manajemen perencanaan kepala sekolah. Jurnal Akuntabilitas Manajemen Pendidikan, 8(2), 137-146. doi: https://doi.org/10.21831/jamp.v8i1.31282 


\section{PENDAHULUAN}

Manajemen merupakan suatu proses dalam rangka mencapai tujuan tertentu melalui usaha pemanfaatan sumber daya manusia dan material secara efisien (Buford \& Bedeian, 1988). Manajemen juga didefinisikan sebagai proses mengatur dan menggabungkan segala aktifitas pekerjaan bersama orang lain sehingga pekerjaan itu dapat diselesaikan secara efisien dan efektif (Robbins \& Coulter, 2012). Sementara itu, Bush (2003) mengartikan manajemen sebagai executive function for carrying agreed polic, yaitu fungsi eksekutif (pelaksanaan) untuk menjalankan kebijakan yang telah disepakati (Bush, 2003). Di bagian lain Bush (2003) juga mengatakan bahwa manajemen berkaitan dengan pemeliharaan dan pengaturan organisasi secara tepat dan cermat sehingga berhasil dan berdaya guna. Dari definisi-definisi tersebut, ada beberapa kata kunci untuk membantu memahami konsep manajemen yakni adanya pemanfaatan sumber daya (yang biasanya disebut input dalam suatu sistem pendidikan), pengkoordinasian dan pengintegrasian aktifitasaktifitas, tujuan sebagai titik yang ingin dicapai, dan sifat efektif dan efisien, serta dengan atau melalui orang lain. Jika makna yang terkandung dalam kata-kata kunci tersebut tidak terpenuhi, maka suatu proses tidak dapat dikatakan sebagai manajemen.

Dalam sistem pendidikan, pemanfaatan sumber daya dan semua aktivitas pendidikan, harus diatur dan digabungkan melalui fungsi-fungsi manajemen. Oleh banyak ahli fungsi-fungsi manajemen ini diidentifikasi secara berbeda-beda, namun tidak perlu diperdebatkan karena semua rumusan memiliki esensi yang sama. Dari banyak pendapat, dapat disimpulkan lima fungsi yang senantiasa ada dalam manajemen sebuah organisasi yakni: perencanaan (planning), pengorganisasian (organizing), pengembangan staf (staffing), pengarahan (leading), dan pengawasan (controlling). Dengan demikian dapat digaris bawahi pengertian manajemen pendidikan secara luas yakni proses pengkoordinasian, pengintegrasian dan pemanfaatan semua aktivitas dan sumber daya pendidikan secara efisien dan efektif melalui fungsi-fungsi manajemen berdasarkan jalur, jenis dan jenjang pendidikan, untuk mencapai tujuan pendidikan (Sonhadji \& Huda, 2015).

Berdasarkan pokok-pokok pikiran tersebut maka perlu direncanakan aktifitas-aktifitas secara matang guna memenuhi berbagai kebutuhan dan pencapaian tujuan organisasi di bidang pendidikan. Buford dan Bedeian (1988) berpendapat bahwa di dalam sebuah manajemen organisasi, perencanaan memiliki kedudukan yang sangat strategis, karena melalui aktifitas perencanaan, tujuan organisasi dapat ditentukan dan proses pemilihan tindakan masa depan untuk mencapai tujuan dapat dilakukan. Dengan kata lain perencanaan merupakan basis bagi pelaksanaan fungsi-fungsi manajemen organisasi lainnya yakni pengorganisasian, pengembangan SDM, pengarahan, dan pengendalian. Dapat dikatakan bahwa upaya peningkatan mutu suatu organisasi di bidang pendidikan dalam mencapai tujuannya harus dimulai dari faktor perencanaan yang baik.

Pentingnya faktor perencanaan dalam sebuah organisasi pendidikan ini diatur pula dalam Peraturan Menteri Pendidikan Nasional Nomor 19 Tahun 2007 tentang Standar Pengelolaan Pendidikan oleh Satuan Pendidikan Dasar dan Menengah (Permendiknas, 2007). Di dalam permendiknas ini dikatakan bahwa setiap satuan pendidikan wajib memenuhi standar pengelolaan pendidikan yang berlaku secara nasional. Standar Pengelolaan yang dimaksud meliputi: perencanaan program, pelaksanaan rencana kerja bidang pendidikan, serta pengawasan dan evaluasi terhadap program kerja. Ketiga standar pengelolaan pendidikan ini merupakan faktor penentu kualitas sebuah lembaga pendidikan. Atau dengan perkataan lain dapat dijelaskan bahwa implementasi manajemen mutu suatu lembaga pendidikan hanya dapat tercapai sangat ditentukan oleh ketiga standar pengelolaan pendidikan.

Ketiga hal tersebut dapat tercapai dengan bergantung pada sumber daya manusia dalam sebuah lembaga pendidikan yakni pimpinan. Kepala sekolah harus memiliki paradigma baru dalam mengimplementasikan dan mengembangkan prinsip-prinsip budaya mutu dalam lembaga yang dipimpinnya. Paradigma atau kerangka berpikir baru ini tentu sangat dibutuhkan dalam upaya mengembangkan kualitas pendidikan di tengah zaman yang penuh perubahan. Oleh karena itu, agar prinsip-prinsip tersebut dapat terwujud, maka perlu ada strategi. Dan strategi yang kiranya tepat untuk menjawab hal tersebut adalah Total Quality Management (TQM).

TQM berkaitan dengan penciptaan budaya mutu suatu organisasi yang harus dilaksanakan secara total, bertahap, dan berkelanjutan. Tujuannya agar karyawan dan staf dapat memberikan 
kepuasan kepada pelanggan selain dukungan struktur organisasi (Ramdass \& Kruger, 2006, p. 9). Menurut Tjiptono dan Diana (2000, p. 4), TQM merupakan suatu pendekatan dalam mengembangkan usaha untuk memaksimalkan daya saing organisasi melalui perbaikan yang terus-menerus atas produk, jasa, manusia, proses, dan lingkungannya. Usaha tersebut harus dimulai oleh kepala sekolah dari proses perencanaan program yang matang. TQM adalah hasil perbaikan dalam hal kualitas. Ini dimulai oleh Walter Shewhart pada awal 1920an ketika kontrol kualitas produk diterapkan dengan teori statistik. Setelah itu pada tahun 1940an yang dipimpin oleh orang Amerika seperti Deming, Juran, Feigenbaum dan Crosby, konsep tersebut dikembangkan lebih lanjut di Jepang. Fokusnya diperluas ke kualitas semua masalah dalam organisasi. Empat fase evolusi kualitas adalah inspeksi, kontrol kualitas, jaminan kualitas, kemudian TQM (Othman, Ghani, \& Choon, 2019)

Sebagai seorang pemimpin, kepala sekolah dituntut harus mampu mempengaruhi para stafnya dalam upaya memperbaiki kelompok dan budayanya, memotivasi perilaku para stafnya dan menentukan tujuan organisasi (Mulyadi, 2010). Hal ini sejalan dengan pendapat yang dikemukakan oleh Junaidah (2016) bahwa kepemimpinan pendidikan dalam era desentralisasi adalah kemampuan yang dimiliki oleh seseorang untuk dapat mempengaruhi, mendorong, mengajak, menuntun, dan menggerakkan orang atau kelompok agar dapat membantu tercapainya suatu tujuan tertentu yang telah ditetapkan. Dengan kata lain, kepemimpinan dapat diartikan sebagai seni memengaruhi dan mengarahkan staf agar dapat percaya, patuh, hormat dan mampu bekerjasama dalam mencapai tujuan bersama (Rivai \& Mulyadi, 2012). Oleh karenanya, salah satu syarat untuk memenuhi mutu pendidikan adalah dengan menerapkan desentralisasi (Junaidah, 2016) di dalam sekolah terhadap tugas-tugas dan program lainnya yang dimulai dari manajemen perencanaan. Melalui desentralisasi, kepala sekolah dapat memiliki kewenangan untuk menyusun perencanaan sekolah, memimpin pelaksanaan program, menentukan visi dan misi, membagi tugas kepada para staf, dan melakukan pengawasan serta perbaikan sesuai dengan kebutuhan sekolah (Sagala, 2010:170).

Mengingat betapa pentingnya peran dan kewenangan yang dimiliki kepala sekolah sebagai pemimpin dalam upaya meningkatkan mutu organisasi pendidikan, maka tujuan peneliti melakukan riset ini adalah untuk menganalisis implementasi Total Quality Management (TQM) dalam sistem manajemen perencanaan kepala sekolah pada Sekolah Menengah Atas (SMA) Swasta Katolik.

\section{METODE}

Penelitian ini mengambil kasus di lembaga pendidikan SMA Swasta Katolik Frateran Malang yang beralamat di Jl. Jaksa Agung Suprapto No. 21, Samaan, Klojen, Kota Malang, Jawa Timur. Penelitian ini menggunakan rancangan pendekatan kualitatif, maksudnya adalah peneliti tidak memberikan treatment (perlakuan) melainkan hanya mengungkap data sesuai tujuan penelitian (Supriyanto, 2011). Variabel penelitian ini berkaitan dengan implementasi TQM dalam sistem manajemen perencanaan kepala sekolah. Uraian tentang variabel, sub variabel, dan indikatornya dapat dilihat pada Tabel 1.

Tabel 1. Variabel, Sub-variabel, dan Indikator Penelitian

\begin{tabular}{|c|c|c|}
\hline Variabel & Sub Variabel & Indikator \\
\hline $\begin{array}{l}\text { Implementasi } \\
\text { TQM dalam } \\
\text { Sistem } \\
\text { Manajemen } \\
\text { Perencanaan } \\
\text { Sekolah }\end{array}$ & $\begin{array}{l}\text { Pengawasan dan Evaluasi } \\
\text { terhadap program kerja } \\
\text { Sistem Informasi } \\
\text { Manajemen }\end{array}$ & $\begin{array}{l}\text { Rumusan Visi dan Misi } \\
\text { Rumusan Tujuan } \\
\text { Rencana Kerja Sekolah: Program Tahunan Kepala } \\
\text { Sekolah dan Program Jangka Panjang Kepala Sekolah. } \\
\text { Dokumen Pedoman Sekolah. } \\
\text { Struktur Organisasi Sekolah } \\
\text { Pelaksanaan Aktivitas Sekolah } \\
\text { Program Monitoring dan Evaluasi: } \\
\text { Dokumen Rencana Pengembangan Sekolah } \\
\text { Fasilitas informasi } \\
\text { Komunikasi antar warga }\end{array}$ \\
\hline
\end{tabular}


Sumber data atau informan dalam penelitian ini adalah kepala sekolah dan para wakil kepala sekolah. Selain itu peneliti juga memanfaatkan sumber data lain berupa guru-guru dengan tujuan untuk memperkuat data, mengingat situasi, dan kondisi sekolah berupa (kesibukan, waktu, dan keakuratan sumber informasi, dari informan kunci). Pemilihan informan ini didasarkan pada kesediaan responden, keakuratan data yang diberikan, dan dapat dipercaya. Untuk memperoleh data, peneliti menggunakan teknik wawancara, observasi, dan studi dokumentasi (Sugiyono, 2019). Analisis data penelitian, guna mengungkap gambaran keberhasilan implementasi konsep TQM dalam sistem manajemen kepala sekolah, peneliti menggunakan teknik analisis deskriptif. Teknik analisis data yang digunakan meliputi reduksi data, penyajan data, menarik kesimpulan atau verifikasi data, dan pengecekan keabsahan data menggunakan teknik triangulasi data (Miles \& Huberman, 2014).

\section{HASIL DAN PEMBAHASAN}

Hasil

Identifikasi terhadap hasil penelitian ini dilakukan berdasarkan urutan variabel penelitian yang telah ditetapkan. Berdasarkan variabel maka ada empat aspek yang diungkap dalam proses penelitian ini. Pertama, perencanaan program sekolah. Hasil analisis data menunjukan bahwa kepala sekolah bersama staf guru telah menyusun rencana program sekolah bidang pendidikan yang meliputi: perumusan visi dan misi satuan pendidikan, rencana kerja satuan pendidikan yakni program tahunan, dan program jangka panjang kepala sekolah. Semua rencana program tersebut dirasa cukup jelas karena sudah tertuang dalam program kerja kepala sekolah.

Kedua, pelaksanaan rencana kerja. Hasil identifikasi data menunjukan bahwa pelaksanaan rencana kerja sudah dilakukan oleh kepala sekolah dan sudah memenuhi tujuan yang diharapkan. Hal ini dapat dilihat dari dokumen-dokumen yang dihasilkan dan kegiatan-kegiatan yang sudah dilakukan oleh kepala sekolah dan para tenaga pendidik di lembaga SMA Swasta Katolik. Sistem manajemen perencanaan kepala sekolah sebagai bentuk implementasi TQM pada tahap kedua ini menghasilkan 3 hal yakni: 1.) Dokumen pedoman sekolah yang meliputi 11 (sebelas) dokumen program; 2.) Penyusunan struktur organisasi sekolah; dan 3.) Pelaksanaan kegiatan sekolah. Dalam implementasinya, setiap kegiatan yang dilakukan oleh semua warga sekolah selalu didasarkan pada rencana kerja tahunan yang telah disusun bersama. Pelaksanaan rencana kegiatan ini dilakukan berdasarkan ketersediaan sumber daya yang ada di sekolah seperti wakil kepala urusan (wakasek) dan para penanggung jawab bidang sesuai struktur organisasi sekolah. Begitu pula kepala sekolah selalu mempertanggungjawabkan pelaksanaan rencana kerja ini setiap tahun bersama para dewan pendidik dan komite sekolah sesuai kewenangannya. Meskipun demikian diakui bahwa pelaksanaan rencana kerja yang sudah baik ini sering terhambat oleh banyak faktor dalam implementasinya, seperti mentalitas manpower dan waktu.

Ketiga, pengawasan dan evaluasi. Data hasil identifikasi menunjukan bahwa proses pelaksanaan monitoring dan evaluasi belum berjalan baik seperti yang diharapkan. Hal ini nampak jelas pada pelaksanaan supervisi kepala sekolah yang belum berjalan efektif. Selain itu pelaksanaan program evaluasi hampir di semua bidang kegiatan masih sangat kurang. Sumber permasalahan supervisi terletak pada pemahaman yang terbatas akan kegiatan supervisi, baik oleh supervisor maupun guru yang disupervisi. Persoalan evaluasi dapat diamati dari hasil kegiatan evaluasi terhadap program pengembangan kurikulum, evaluasi tenaga pendidik, dan kependidikan yang belum berjalan maksimal. Persoalan ini kiranya menjadi prioritas pembenahan yang harus terus diupayakan. Meskipun demikian, terdapat hal positif yang kiranya menjadi kekuatan lembaga yakni adanya program supervisi dan evaluasi yang sudah disusun secara obyektif dan bertanggung jawab. Begitu pula program akreditasi sekolah cukup mendapat perhatian yang baik dalam implementasinya. Hal ini terbukti dari predikat akreditasi A yang diperoleh sekolah dari BAN/SM.

Sistem Informasi Manajemen, salah satu aspek penting dalam sistem manajemen perencanaan sebuah lembaga adalah aspek informasi manajemen. Dari hasil identifikasi ditemukan bahwa aspek komunikasi informasi manajemen di lembaga pendidikan ini cukup tersedia. Banyak sarana komunikasi yang disediakan oleh lembaga ini seperti telepon (handphone) sekolah, wifi, CCTV, dan komputer. Dalam penerapannya, sarana-sarana tersebut mudah diakses dan cukup efektif 
membantu proses komunikasi dan informasi dalam kegiatan intern lembaga. Fasilitas komputer untuk memperlancar kegiatan perencanaan dan pengelolaan data administrasi cukup memadai. Sekolah juga memiliki tenaga khusus bagian humas untuk membangun komunikasi dengan pihak ekstern seperti dinas, orang tua wali, dan instansi lainnya. Budaya komunikasi interpersonal dalam lingkup internal lembaga terjalin baik berkat adanya budaya 3S (senyum, salam, dan sapa). Meskipun demikian mereka menyadari bahwa hambatan informasi manajemen dalam sebuah lembaga pasti selalu ada, namun hal itu dapat diminimalisir berkat adanya ketersediaan sarana prasarana yang memadai dan juga faktor keterbukaan.

Berdasarkan data-data temuan tersebut, maka digambarkan sebuah model implementasi TQM sesuai variabel, sub-variabel, dan indikator penelitiannya. Model Implementasi TQM pada sistem manajemen perencanaan sekolah dapat dilihat pada Gambar 1.

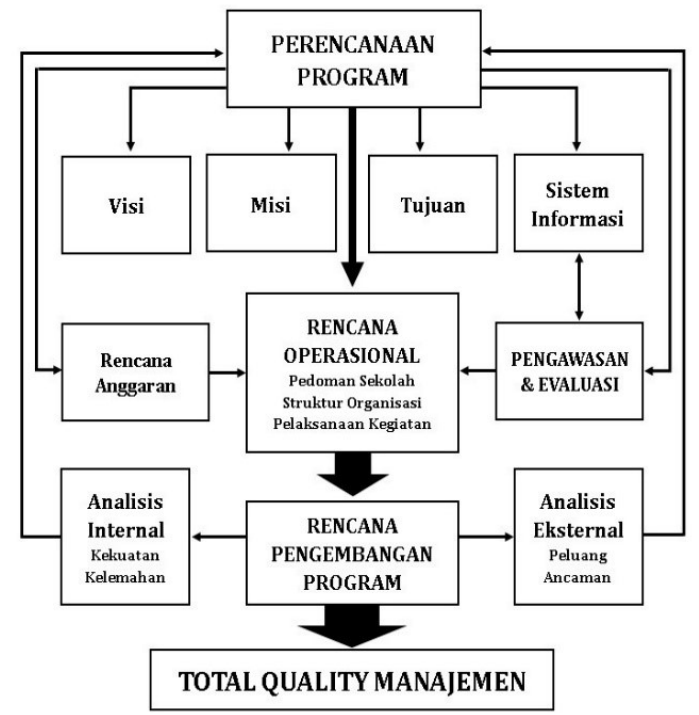

Gambar 1. Model Sistem Manajemen Perencanaan Sekolah

Pembahasan

Implementasi TQM dalam manajemen Perencanaan SMA Swasta Katolik secara umum menunjukkan hasil yang positif. Hal ini dapat dilihat dari dokumen yang telah dihasilkan sekolah yang memuat rumusan Visi dan Misi satuan pendidikan, rumusan Tujuan dan Rencana Kerja Bidang Pendidikan berupa Program Tahunan dan Program Kerja Jangka Panjang Kepala Sekolah. Dokumen yang memuat rumusan dan berbagai perencanaan program yang telah dihasilkan ini, menunjukkan bahwa kepala sekolah dan para tenaga pendidik memiliki komitmen dan etos kerja dalam mendukung budaya mutu di lingkungan sekolah (lembaga pendidikan). Perencanaan dan penyusunan program yang jelas dan terarah ini merupakan wujud konkret upaya sekolah dalam menciptakan budaya mutu bagi semua warga sekolah. Kesadaran dan tanggung jawab ini tentu memiliki peran penting dalam mendukung proses perubahan sosial di tengah masyarakat. Lebih-lebih bila peran ini dilakukan secara konsisten akan menghasilkan pelayanan jasa yang sangat bermanfaat bagi lembaga pendidikan (Supriyanto, 2011). Hal ini sejalan dengan apa yang dikatakan oleh Suryana (2017) bahwa pendidikan dalam perspektif sosialnya, akan melahirkan insan-insan terpelajar yang memiliki peranan penting dalam proses perubahan sosial di dalam masyarakat.

Di sisi lain, pentingnya perencanaan program kerja sekolah yang baik dapat membantu semua warga dalam memahami tugas dan fungsinya secara jelas. Tujuannya agar semua warga di dalam satuan pendidikan ikut ambil bagian dalam mewujudkan wawasan dan tujuan institusi pendidikan (sekolah). Hasil analisis menunjukan bahwa rumusan visi, misi dan tujuan SMA Swasta Katolik sudah searah dengan sasaran utama TQM yakni kepuasan pelanggan baik internal maupun eksternal. Dengan kata lain aspek pertama dalam sistem manajemen perencanaan yang dilakukan 
kepala SMA Swasta Katolik yakni perencanaan program sudah mencerminkan implementasi TQM dalam lembaga pendidikan yang dipimpinnya. Hal itu bisa dilihat dari program-program yang telah dihasilkan oleh sekolah. Manajemen perencanaan program yang dimaksud di sini tentu harus sejalan dengan standar nasional pendidikan sebagai indikator mutu layanan manajemen sekolah. Triwiyanto (2013) menegaskan bahwa indikator mutu layanan tersebut meliputi: tujuan, prinsip, dan jenis layanan. Lebih lanjut ia mengatakan bahwa salah satu aktivitas penting sekolah yang menunjukan indikator layanan manajemen ini adalah kegiatan yang dilakukan melalui perencanaan program.

Masih dalam lingkup perencanaan program terdapat pula program-program lain yang disusun untuk memberikan arah dan membantu warga sekolah terkait dengan tugas pokok dan fungsinya telah disusun secara sistematis dan terprogram. Program-program itu antara lain: program kerja kepala sekolah yang mencakup program kerja jangka panjang dan program kerja tahunan kepala sekolah, program tata usaha, program urusan kurikulum, program urusan kepesertadidikan, program urusan hubungan masyarakat, program urusan sarana prasarana, program perpustakaan, program PPK dan program literasi. Semuanya itu tentu diarahkan semata-mata demi kepuasan pelanggan, perbaikan proses dan pelibatan anggota dalam proses penyusunannya. Namun perlu disadari bahwa sebaik apapun program jika pada sistem perencanaannya masih bersifat top-down maka akan menciptakan kegagalan, karena perencanaan program yang baik harus bersifat bottom-up dengan menggunakan pendekatan partisipatif dan mengikuti siklus PDCA yang ditawarkan Deming yakni plan, do, check, dan adjust (Sutarto, 2015).

Variabel pelaksanaan rencana kerja bidang pendidikan, mengacu pada struktur organisasi, dokumen pedoman satuan pendidikan, dan pelaksanaan aktivitas sekolah. Tiga aspek ini merupakan satu kesatuan dan telah disusun secara baik di SMA Swasta Katolik. Suatu organisasi yang baik harus memenuhi tiga aspek ini dalam pelaksanaan rencana kerja. Sebuah rencana kerja hanya dapat terwujud jika ditindaklanjuti dengan pelaksanaan yang inovatif, professional, dan motivasi yang tinggi dari setiap pelaku kegiatan yang ada di lingkungan lembaga pendidikan (Kementerian Riset dan Teknologi Republik Indonesia, 2015). Namun implementasi TQM akan berdaya efektif jika lembaga memiliki pedoman yang jelas dan struktur organisasi yang baik yang berfungsi untuk mengatur tugas dan kewajiban para anggota dalam pelaksanaannya.

Dalam penelitian ini ditemukan bahwa dalam realisasinya lembaga pendidikan SMA Swasta Katolik ini sudah memiliki struktur organisasi yang dapat membantu mengatur tugas dan wewenang semua anggota lembaga. Demikian pula dalam pedoman sekolah, tugas dan wewenang tersebut sudah dirinci secara jelas sehingga sangat membantu para tenaga pendidik dan para staf dalam menjalankan tugas dan wewenangnya. Rasa saling menghormati satu dengan yang lain cukup mewarnai kehidupan para warga di lembaga ini. Begitu pula nilai gotong royong, saling membantu adalah budaya mutu yang senantiasa dikembangkan di lembaga ini dalam mewujudkan rencana kerja sekolah. Semua warga memberikan kontribusi positif sesuai dengan satuan tugas yang telah ditetapkan dalam meningkatkan budaya mutu. Faktor budaya dan iklim organisasi yang efektif seperti inilah yang harus terus dipertahankan dan dibangun secara berkelanjutan oleh lembaga pendidikan yang bermutu.

Temuan ini mendukung apa yang dikemukakan oleh Fadhli (2017) bahwa salah satu indikator pendidikan bermutu adalah apabila sekolah memiliki budaya dan iklim organisasi yang efektif. Meskipun demikian diakui bahwa pelaksanaan rencana kerja yang sudah baik ini sering terhambat oleh banyak faktor dalam implementasinya, seperti mentalitas manpower dan waktu. Oleh karena itu, perlu usaha yang terencana dalam mengelola dan membina mentalitas dan kedisiplinan secara terus menerus bagi para warga sekolah terutama tenaga pendidik dan tenaga kependidikan. Faktor penting lain yang mendukung pelaksanaan rencana kerja dapat terwujud yakni tindakan partisipatif yang harus dilakukan oleh pemimpin. Caranya yakni mengkoleksi input dari staf, menelusuri, peduli, bekerja bersama staf untuk meningkatkan mutu input atau penghargaan kepada staf atas perbaikan inputnya (Goetsch \& Davis, 1994). Hal tersebut merupakan gaya kepemimpinan partisipatif yang diharapkan yang semestinya diterapkan di dalam seting kepemimpinan mutu terpadu (Sutarto, 2015).

Dalam implementasinya di lembaga pendidikan SMA Swasta Katolik, peran pemimpin yang berjiwa partisipatif seperti peduli, bekerja bersama staf dan pemberian penghargaan kepada staf, cukup memberikan dukungan terhadap penerapan budaya mutu. Perhatian terhadap perilaku 
bawahan ini merupakan salah satu budaya mutu yang dikembangkan di lembaga pendidikan SMA Swasta Katolik, karena turut mempengaruhi proses pengambilan keputusan pimpinan. Hasil temuan ini sejalan dengan apa yang dikemukakan oleh Faturahman (2018) dalam penelitiannya tentang kepemimpinan dalam budaya organisasi. Di sisi lain penerapan gaya kepemimpinan partisipatif dan komunikasi organisasi ini, berpengaruh juga terhadap peningkatan motivasi kerja dan hasil kinerja para karyawan (staf) seperti temuan yang dilakukan oleh Rokib dan Santoso (2018), serta Syaiyid, Utami, dan Riza (2013).

Gaya kepemimpinan seperti yang digambarkan di atas erat kaitannya dengan pengawasan dan evaluasi yang juga merupakan unsur penting dalam sebuah manajemen organisasi. Proses pelaksanaan pengawasan dan evaluasi di lembaga pendidikan SMA Swasta Katolik dalam sistem manajemen perencanaan cukup berjalan baik. Hal ini terbukti dengan adanya program pengawasan dan evaluasi yang telah disusun secara objektif dan bertanggung jawab. Dalam rangka implementasi TQM, kepala sekolah sudah membentuk sebuah unit pengembangan mutu sekolah. Anggotanya berjumlah sembilan orang yang direkrut dari berbagai pihak diantaranya kepala sekolah, komite sekolah dan beberapa tenaga pendidik yang ditunjuk dari lembaga bersangkutan. Prinsip pengelolaannya dalam sebuah lembaga pendidikan sangat penting sebagai tolok ukur untuk menilai keberhasilan dan kegagalan penerapan manajemen mutu sekolah (Ginting \& Haryati, 2012). Tugas utama unit mutu ini adalah melakukan identifikasi hal-hal yang berkaitan dengan kekuatan dan kelemahan yang dimiliki serta peluang dan ancaman yang dihadapi sekolah melalui analisis SWOT.

Hasil analisis yang ditemukan membantu tim menyusun rencana pengembangan sekolah. Program-program yang telah dihasilkan unit mutu ini antara lain program pendidikan karakter, program pengembangan bakat dan minat, program lingkungan sekolah hijau, program pembelajaran berbasis IT, dan program life skill. Upaya yang telah dilakukan lembaga pendidikan SMA Swasta Katolik ini menunjukkan bahwa lembaga ini cukup berkomitmen terhadap penerapan TQM. Hal ini tentu tidak akan berjalan tanpa kehadiran pemimpin yang dapat memahami manajemen mutu. Oleh karena itu, aspek pemimpin dan manajemen mutu merupakan dua hal yang sangat mempengaruhi kualitas sebuah lembaga pendidikan. Ginting dan Haryati (2012) dalam penelitiannya menegaskan bahwa upaya peningkatan mutu pendidikan dapat seyogyanya dapat dilakukan melalui penerapan prinsip-prinsip manajemen sumber daya manusia (human resource management) guna mewujudkan kepala sekolah yang handal dan berkualitas.

Meskipun demikian diakui juga bahwa dalam implementasinya masih terdapat pula hal-hal yang belum berjalan sesuai harapan. Salah satunya adalah pelaksanaan supervisi kepala sekolah yang belum berjalan secara efektif. Sumber permasalahannya berasal dari pemahaman yang terbatas akan pentingnya supervisi baik oleh supervisor maupun guru yang disupervisi. Oleh karena itu, kegiatan pelatihan supervisi adalah solusi prioritas yang perlu diperhatikan secara serius di dalam lembaga SMA Swasta Katolik. Penyusunan program pengawasan dan evaluasi diakui sudah dilakukan secara bertanggungjawab sesuai standar nasional pendidikan. Namun pada implementasinya dirasa masih harus mendapat prioritas pembenahan. Program monitoring dan evaluasi pada bidang yang lain pun masih perlu ditingkatkan diantaranya adalah evaluasi pengembangan kurikulum dan evaluasi pendayagunaan pendidik dan tenaga kependidikan. Sementara program akreditasi sekolah cukup baik dalam implementasinya. Hal ini terbukti dari predikat akreditasi A yang diperoleh sekolah dari BAN/SM.

Fasilitas informasi suatu lembaga pendidikan adalah salah satu tuntutan di era industri 4.0. Memasuki kehidupan abad 21, lembaga SMA Swasta Katolik dalam sistem manajemen perencanaan telah mempersiapkan diri menghadapi tuntutan teknologi informasi. Kebutuhan akan tersedianya fasilitas informasi yang mudah dan cepat diakses, serta tepat sasar dan akurat menjadi dasar pertimbangan dalam perencanaan pengembangan sarana informasi di berbagai lembaga organisasi termasuk SMA Swasta Katolik. Sama seperti lembaga pendidikan lainnya, SMA Swasta Katolik juga memanfaatkan teknologi informasi untuk seluruh proses kegiatan pendidikan (Rahmawati, 2012). Oleh karena itu, berbagai fasilitas teknologi informasi diupayakan lembaga guna mendukung implementasi budaya mutu. Namun dalam pemanfaatannya tetap memperhitungkan dan menyesuaikan dengan kebutuhan, sifat, dan tujuan perencanaannya (Subarjo, 2015).

Fasilitas komputer dan internet untuk memperlancar perencanaan dan pengelolaan data administrasi dan proses pembelajaran di SMA Swasta Katolik juga cukup memadai. Sekolah 
memiliki jaringan wifi yang dapat diakses oleh semua warga sekolah. Selain fasilitas teknologi informasi, sekolah juga memiliki tenaga khusus bagian humas untuk membangun jejaring komunikasi dengan pihak eksternal seperti dinas, orang tua wali, dan instansi lainnya. Mereka selalu memanfaatkan media jejaring sosial dalam membangun komunikasi interpersonal dengan semua stakeholder, dengan sasaran utamanya adalah kepuasan pelanggan yang dilayani.

Cara yang ditempuh pihak sekolah ini turut mendukung hasil penelitian yang dilakukan oleh Al Rasyid (2017) tentang Pengaruh kualitas layanan dan pemanfaatan teknologi terhadap kepuasan dan loyalitas pelanggan Go-Jek. Budaya komunikasi interpersonal dalam lingkup internal lembaga terjalin baik berkat adanya budaya $3 \mathrm{~S}$ (senyum, salam, dan sapa). Dari hasil identifikasi ditemukan juga bahwa sarana komunikasi informasi lainnya di lembaga pendidikan ini cukup tersedia diantaranya telepon (handphone), wifi, CCTV, komputer dan sarana pendukung lainnya. Keberadaan saranasarana komunikasi ini disediakan lembaga dengan tujuan untuk memperlancar kegiatan pendidikan dan membantu informasi yang efisien dan efektif dalam proses pembelajaran.

Pentingnya peranan teknologi dalam dunia pendidikan ini menurut Sudibyo dan Sujono (2011) meliputi teknologi informasi, ketrampilan (skill), kompetensi, infrastruktur pendidikan, sumber bahan ajar, alat bantu, fasilitas pendidikan, dan manajemen pendidikan. Mengingat betapa pentingnya sarana teknologi komunikasi dan informasi dalam suatu lembaga pendidikan, maka perlu juga suatu perencanaan yang matang baik mengenai pengadaan, penggunaan maupun pemeliharaannya. Sarana-sarana tersebut tentu sangat dibutuhkan lembaga di era digital. Selain itu lembaga SMA Swasta Katolik juga dalam sistem perencanaannya menjalin komunikasi dengan berbagai media elektronik dan non elektronik dari pihak luar. Semua sarana informasi ini diupayakan dalam sistem manajemen perencanaan dengan tujuan untuk mendukung publikasi lembaga kepada pihak eksternal dan dalam upaya mengimplementasikan Total Quality Management (TQM).

\section{SIMPULAN}

Pada sistem manajemen perencanaan, pertama, kepala sekolah bersama tim telah menyusun berbagai perencanaan program sekolah guna mendukung budaya mutu di lingkungan sekolah, yang meliputi: perumusan visi dan misi serta tujuan sekolah. Begitu pula telah disusun berbagai Rencana Kerja Sekolah (RKS) dengan aneka program yang dihasilkan yakni: 1.) program kerja jangka pendek dan jangka panjang kepala sekolah, program monitoring dan evaluasi, supervisi, tata usaha, kurikulum, peserta didik, humas, sarpras, perpustakaan, PPK dan literasi; 2.) Dalam sistem manajemen perencanaan, kepala sekolah bersama dewan guru dan staf telah melaksanakan rencana kerja bidang pendidikan sesuai tupoksi dan kewajiban para staf dan tenaga pendidik seperti yang ada dalam dokumen pedoman sekolah dan struktur organisasi sekolah melalui berbagai kegiatan sekolah yang telah diprogramkan. Meskipun demikian diakui bahwa pelaksanaan rencana kerja yang sudah baik ini sering terhambat oleh banyak faktor dalam implementasinya, seperti mentalitas manpower dan waktu; 3.) Dalam sistem manajemen perencanaan, kepala sekolah telah melakukan pengawasan dan evaluasi terhadap seluruh proses kegiatan sesuai yang tertuang dalam program kerja sekolah. Namun pelaksanaannya belum berjalan efektif karena kurangnya pemahaman supervisor dan guru tentang supervisi. Kepala Sekolah bersama tim telah membentuk unit pengembangan mutu sekolah dan menyusun dokumen RPS (Rencana Pengembangan Sekolah) yang didahului dengan identifikasi kebutuhan, melakukan analisis SWOT dan menyusun RPS yang berisi 5 program unggulan antara lain: program pendidikan karakter, program pengembangan bakat dan minat, program lingkungan sekolah hijau, program pembelajaran berbasis IT dan program life skill khususnya perhotelan dan desain komunikasi visual; dan 4.) Dalam sistem manajemen perencanaan, kepala sekolah bersama staf dan dewan guru telah membangun sistem informasi manajemen guna mendukung pengimplementasian budaya mutu dalam seluruh aspek baik fisik maupun nonfisik.

\section{DAFTAR PUSTAKA}

Al Rasyid, H. (2017). Pengaruh kualitas layanan dan pemanfaatan teknologi terhadap kepuasan dan loyalitas pelanggan Go-Jek. Jurnal Ecodemica: Jurnal Ekonomi, Manajemen, dan Bisnis, 1(2), 210-223. doi: https://doi.org/10.31294/jeco.v1i2.2026 
Buford, J. A., \& Bedeian, A. G. (1988). Management in extension. Auburn: Alabama Cooperative Extension Servis, Auburn University.

Bush, T. (2003). Theories of educational leadership and management ( $3^{\text {rd }}$ ed.). Thousand Oaks: SAGE Publications Ltd.

Fadhli, M. (2017). Manajemen peningkatan mutu pendidikan. Tadbir: Jurnal Studi Manajemen Pendidikan, 1(2), 215-240. doi: http://dx.doi.org/10.29240/jsmp.v1i2.295

Faturahman, B. M. (2018). Kepemimpinan dalam budaya organisasi. Madani Jurnal Politik dan Sosial Kemasyarakatan, 10(1), 1-11. Retrieved from http://www.ejurnal.unisda.ac.id/index.php/MADANI/article/view/186

Ginting, R., \& Haryati, T. (2012). Kepemimpinan dan Konteks Peningkatan Mutu Pendidikan. Jurnal Ilmiah CIVIS, 2(2). $\quad$ Retrieved from http://journal.upgris.ac.id/index.php/civis/article/viewFile/455/409

Goetsch, D., \& Davis, D. (1994). Introduction to total quality management: Quality, productivity, competitiveness. Upper Saddle River: Prentice-Hall Int. Inc.

Junaidah, J. (2016). Kepemimpinan transformasional dalam pendidikan. Al-Idarah: Jurnal Kependidikan Islam, 6(2), 100-118. doi: https://doi.org/10.24042/alidarah.v6i2.802

Kementerian Pendidikan Nasional Republik Indonesia. (2007). Peraturan Kementerian Pendidikan Nasional Republik Indonesia Nomor 19 Tahun 2007 tentang Standar Pengelolaan Pendidikan oleh Satuan Pendidikan Dasar dan Menengah. Retrieved from http://simpuh.kemenag.go.id/regulasi/permendiknas 19 07.pdf

Kementerian Riset dan Teknologi Republik Indonesia. (2015). Rencana strategis 2015-2019: Direktorat Jendral Penguatan Riset dan Pengembangan. Retrieved from http://risbang.ristekdikti.go.id/wp-content/uploads/2018/01/Renstra-Dirjen-Risbang-20152019.pdf

Miles, M. B., \& Huberman, A. M. (2014). Analisis data kualitatif. Jakarta: Universitas Indonesia Press.

Mulyadi, M. (2010). Kepemimpinan kepala sekolah dalam mengembangkan budaya mutu. Malang: UIN Maliki Press.

Othman, I., Ghani, S. N. M., \& Choon, S. W. (2020). The total Quality Management (TQM) journey of Malaysian building contractors. Ain Shams Engineering Journal, 11(3), 697-704. Doi: https://doi.org/10.1016/j.asej.2019.11.002

Rahmawati, D. (2012). Analisis faktor-faktor yang berpengaruh terhadap pemanfaatan teknologi informasi. Jurnal Ekonomi Dan Pendidikan, 5(1), 107-118. doi: https://doi.org/10.21831/jep.v5i1.606

Ramdass, K., \& Kruger, D. (2006). Repositioning quality culture in higher education. Johannesburg: University of Johannesburg.

Rivai, V., \& Mulyadi, D. (2012). Kepemimpinan dan perilaku organisasi. Jakarta: Rajawali Pers.

Robbins, S. P., \& Coulter, M. (2012). Management (1 $1^{\text {th }}$ ed). London: Pearson Education, Inc.

Rokib, M. N., \& Santoso, D. (2018). Pengaruh gaya kepemimpinan partisipatif dan komunikasi organisasi terhadap kinerja karyawan melalui kepuasan kerja sebagai variabel intervening. Jurnal Riset Ekonomi dan Bisnis, 11(2), 108-127. doi: http://dx.doi.org/10.26623/jreb.v11i2.1080

Sagala, S. (2010). Manajemen strategik dalam peningkatan mutu pendidikan. Bandung: Alfabeta.

Sonhadji, A \& Huda, M. (2015). Asesmen kebutuhan, pengambilan keputusan, dan perencanaan: Matarantai dalam manajemen pendidikan. Universitas Negeri Malang. 
Subarjo, A. H. (2015). Pemanfaatan teknologi informasi untuk pendidikan. Jurnal Angkasa, 7(1), 45-56. Retrieved from http://stta.ac.id/data lp3m/04.Mei2015 AbdulHaris.pdf

Sudibyo, L., \& Sujono, S. (2011). Peranan dan Dampak Teknologi Informasi dalam Dunia Pendidikan di Indonesia. Widyatama, 2(20), 175-185. Retrieved from https://adoc.pub/peranan-dan-dampak-teknologi-informasi-dalam-dunia-pendidika.html

Sugiyono, S. (2019). Metode penelitian pendidikan. Bandung: Alfabeta.

Supriyanto, A. (2011). Implementasi total quality management dalam sistem manajemen mutu pembelajaran di institusi pendidikan. Cakrawala Pendidikan, 1, 17-29. doi: https://doi.org/10.21831/cp.v1i1.4188

Suryana, S. (2017). Permasalahan mutu pendidikan dalam perspektif pembangunan pendidikan. Edukasi, 2(1). Retrieved from https://journal.unnes.ac.id/nju/index.php/edukasi/article/view/971/908

Sutarto, H. (2015). Manajemen mutu terpadu (MMT-TQM): Teori dan penerapan di lembaga pendidikan. Yogyakarta: UNY Press.

Syaiyid, E., Utami, H., \& Riza, M. (2013). Pengaruh gaya kepemimpinan terhadap motivasi kerja (studi pada karyawan radar Malang PT. Malang Intermedia Pers). Jurnal Administrasi Bisnis, $\quad 1(1), \quad 104-113 . \quad$ Retrieved from http://administrasibisnis.studentjournal.ub.ac.id/index.php/jab/article/view/16

Tjiptono, F., \& Diana, D. (2000). Total quality management. Andi Offset.

Triwiyanto, T. (2013). Standar nasional pendidikan sebagai indikator mutu layanan manajemen sekolah. Jurnal Ilmu Pendidikan, 19(2), 161-171. doi: http://dx.doi.org/10.17977/jip.v19i2.4208 